\title{
PENERAPAN GRATITUDE JOURNAL UNTUK MENURUNKAN GEJALA DEPRESIF PADA PENDERITA KANKER: STUDI DENGAN ECOLOGICAL MOMENTARY ASSESSMENT
}

\author{
Eric Sucitra, Samsunuwijati Mar'at, Sri Tiatri \\ Fakultas Psikologi, Universitas Tarumanagara, Jakarta \\ E-mail: eric.717171008@stu.untar.ac.id \\ E-mail: samsunuwijatimarat@yahoo.co.id \\ E-mail: sritiatri@untar.ac.id
}

\begin{abstract}
ABSTRAK
Kanker adalah sebuah masalah medis serius yang memiliki dampak yang signifikan terhadap kualitas hidup penderita secara holistik, termasuk masalah kejiwaan yang mengarah pada gejala depresif. Negative inferential style, yakni sebuah gaya pikir yang cenderung memproses peristiwa hidup secara lebih negatif dari biasanya, diduga sebagai salah satu faktor yang memicu penderita kanker untuk mengembangkan gejala depresif. Studi ini bertujuan untuk memeriksa penerapan intervensi yang berfokus pada aspek kognitif individu dalam bentuk aktivitas gratitude journal untuk mengurangi gejala depresif partisipan. Penelitian ini juga menggunakan ecological momentary assessment untuk memeriksa fluktuasi mood depresif dalam partisipan. Enam partisipan wanita dengan berusia antara 35 sampai 56 tahun $(\overline{\mathrm{x}}=44.83)$ dengan diagnosis kanker dan gejala depresif (skor BDI-II > 0) direkrut dan menyelesaikan aktivitas gratitude journal selama dua minggu. Uji statistik non-parametrik Wilcoxon Signed Rank Test dan Kruskall-Wallis Test dilakukan untuk menganalisis data. Studi ini juga melakukan analisis tematik dalam bentuk coding untuk menemukan protective factors terhadap depresi yang terkandung dalam gratitude journal. Studi ini tidak menemukan perbedaan bermakna pada skor pretest-posttest trait gratitude, namun menemukan penurunan skor yang signifikan pada gejala depresif. Terakhir, peneliti tidak menemukan adanya perbedaan bermakna dalam gejala depresif pada tiga kondisi waktu yang berbeda. Studi ini menunjukkan bahwa gratitude journal dapat digunakan sebagai jenis intervensi yang dapat mendampingi intervensi lain karena karakteristik aktivitasnya yang sederhana. Akan tetapi, masih dibutuhkan penelitian lebih lanjut yang memeriksa penerapan gratitude journal terhadap penderita depresi klinis sebelum konklusi mengenai efektivitas dari aktivitas gratitude journal dapat ditegakkan.
\end{abstract}

Kata Kunci:depresi, gratitude trait, gratitude journal, protective factors

\begin{abstract}
Cancer is a group of medical diseases that has detrimental impacts on the sufferers' quality of life holistically, which includes psychological issues that may lead them to heightened depressive symptoms. Negative inferential style, defined as the tendency to interpret or attribute negative life events in maladaptive ways, has been suggested to be a risk factor contributing to the development of depressive symptoms. The current study aimed to investigate the application of cognitive-based intervention in the form of gratitude journal to reduce depressive symptoms. In addition, the study was designed to explore the fluctuative depressive mood among cancer sufferers by utilizing ecological momentary assessment. Six partisipants with age range from 35 to 56 years old $(\bar{x}=44.83)$, with cancer diagnosis and depressive symptoms (BDI-II >0) were recruited and completed gratitude journal activity for two weeks. Non-parametric statistical analyses in the form of Wilcoxon Signed Rank Test and Kruskall-Wallis Test were conducted to analyse the data. Findings showed no significant differences between gratitude trait pretest-posttest scores. In contrast, there were significant differences among depressive scores, indicating that the intervention helps to reduce depressive symptoms among cancer sufferers. It was further revealed that the analyses failed to find significant depressive symptoms' differences among three different time points. The findings suggest that gratitude journal can be used as an effective side-intervention that complements other type of intervention to reduce depressive symptoms due to its "easy-to-do" nature. However, future research is necessary to establish its efficacy to treat individuals with more serious depressive symptoms.
\end{abstract}

Keywords: depression, gratitude trait, gratitude journal, protective factors. 


\section{PENDAHULUAN}

Kanker merupakan sebuah masalah medis yang bersifat kronis dan dapat mempengaruhi aspek fisik, psikologis, sosial, dan finansial dari kehidupan penderitanya. Secara medis, kanker atau tumor ganas dapat didefinisikan sebagai pertumbuhan sel atau jaringan yang pertumbuhannya tidak dapat dikendalikan dan tidak dapat dimatikan dengan mudah (Kementerian Kesehatan Republik Indonesia [KKRI], 2013). Masalah kanker seringkali bersifat unik pada setiap individu, sehingga penanganan atau kombinasi treatment yang diberikan kepada setiap pasien biasanya bersifat unik juga. Akan tetapi, hal-hal tersebut menyebabkan penanganan masalah kanker itu sendiri memiliki durasi yang lama karena proses identifikasi kanker yang unik pada setiap individu dan penyusunan rencana treatment yang membutuhkan waktu cukup lama. Selain itu, diagnosis kanker dapat memberikan dampak negatif secara signifikan pada kehidupan individu, baik bagi penderita itu sendiri, keluarga dan kerabat, bahkan lingkaran sosial penderita.

Berdasarkan data statistik dari The International Agency for Research on Cancer (IARC; 2013), terdapat estimasi 14.1 juta insiden kanker baru dan 8.2 juta angka kematian karena kanker pada tahun 2012, dibandingkan dengan 12.7 juta dan 7.6 juta pada tahun 2008. Data prevalensi pada tahun 2012 juga menunjukkan bahwa terdapat setidaknya 32.6 juta penduduk berusia di atas 15 tahun yang masih hidup yang memiliki diagnosis kanker pada lima tahun terakhir hidup mereka. Diagnosis kanker yang paling tinggi di seluruh dunia adalah kanker paru-paru (1.8 juta, 13\% dari total diagnosis), kanker payudara (1.7 juta, 11.9\%), dan kolon-rektum (1.4 juta, 9.7\%). Di Indonesia, penyakit kanker merupakan penyebab kematian ketujuh terbesar setelah stroke, tuberculosis, darah tinggi (hipertensi), cedera, masalah perinatal, dan diabetes melitus dengan angka prevalensi setidaknya 1.4 per 1.000 penduduk Indonesia (KKRI, 2013). Angka prevalensi kanker yang tertinggi ditemukan pada D.I. Yogyakarta $(4.1 \%)$, yang kemudian diikuti dengan Jawa Tengah (2.1\%), Bali (2\%), Bengkulu dan DKI Jakarta dengan persentase yang sama (1.9\%) (KKRI, 2013).

Seperti yang telah dipaparkan sebelumnya, masalah kanker memiliki dampak yang signifikan terhadap kualitas hidup penderita secara holistik, tidak hanya secara medis atau fisik saja. Penderita kanker, terutama penderita kanker tahap lanjut, sering mengalami penderitaan fisik, psikososial, masalah kejiwaan seperti depresi dan kecemasan, dan spiritual secara sekaligus (Effendy et al., 2014; Mitchell et al., 2011; Schmid-Büchi, Halfens, Dassen, \& van den Borne, 2011; van den Beuken-van Everdingen et al., 2009). Masalah psikologis yang seringkali terjadi pada penderita kanker di Indonesia adalah kecemasan karena tidak dapat memprediksi masa depan, kambuhnya penyakit, masalah depresi, kambuhnya masalah kanker, ketakutan akan rasa sakit fisik, kesulitan mengekspresikan emosi negatif dalam diri, dan ketakutan akan kematian (Effendy et al., 2014; Whitmer, Pruemer, Nahleh, Jazieh, 2006). Secara umum, 34\% penderita kanker di Indonesia mengalami mood depresif (Effendy et al., 2014).

Terdapat implikasi yang signifikan pada keterkaitan antara diagnosis kanker dan emosi depresif dalam diri individu. Keterkaitan antara keduanya, selain dapat memberikan beban terhadap pasien dan lingkungan sosial di sekitarnya, juga dapat meningkatkan persepsi rasa sakit yang diasosiasikan dengan meningkatnya jumlah hari rawat inap di rumah sakit, menurunkan kerelaan pasien untuk mengikuti proses pengobatan yang juga menurunkan hasil intervensi yang optimal, dan jika tidak ditangani, dapat meningkatkan resiko bunuh diri (Chintamani et al., 2011). Akan tetapi, masih terdapat banyak pasien kanker dengan depresi klinis yang tidak memperoleh intervensi psikologis karena fokus yang terlalu dalam pada aspek fisik saja. Dengan latar belakang masalah yang telah dipaparkan di atas, penting untuk merancang sebuah intervensi yang tidak 
membutuhkan biaya tinggi (karena tekanan biaya perawatan yang telah dijelaskan sebelumnya) yang juga dapat meringankan beban psikologis penderita kanker dengan depresi untuk meningkatkan kualitas hidup penderita.

Dalam literatur saintifik, terdapat berbagai sudut pandang yang berupaya untuk menjelaskan mengapa sebagian orang lebih rentan mengalami atau mengembangkan masalah depresi jika dibandingkan dengan sebagian orang lain, salah satunya adalah teori-teori yang berfokus pada aspek kognitif seseorang. Berdasarkan teori-teori depresi dari sudut pandang kognitif, cara seseorang melihat atau menjelaskan peristiwa-peristiwa dalam hidup mereka sangatlah ditentukan oleh gaya kognitif (cognitive styles) yang mereka miliki, yang dapat mempengaruhi kondisi emosional seseorang secara signifikan. Oleh karena itu, untuk melengkapi kajian literatur ilmiah yang berupaya untuk menjelaskan faktor resiko perkembangan depresi yang menekankan aspek biologis dan genetik, Beck's theory (Beck, 1967) dan the hopelessness theory of depression (Abramson, Metalsky, \& Alloy, 1989) berupaya untuk melengkapi theoretical gap mengenai proses perkembangan depresi dari sudut pandang kognitif.

Dalam studi oleh Giollabhui et al. (2018), mereka berhasil menunjukkan bahwa individu yang memiliki gaya kognitif negatif (negative inferential style) akan cenderung mengembangkan rasa tidak ada harapan (hopelessness) ketika mereka mengalami peristiwa hidup negatif yang signifikan, seperti kecelakaan, sakit-penyakit, maupun kehilangan seseorang yang dikasihi (e.g., anggota keluarga, pasangan hidup, sahabat). Sebagai akibatnya, kecenderungan tersebut dapat meningkatkan kemungkinan seseorang mengembangkan gangguan depresi. Hal yang relatif serupa juga dikemukakan oleh Beck (1967) yang menyatakan hubungan erat antara proses berpikir negatif dengan berkembangnya mood depresif. Oleh karena itu, penyusunan intervensi yang berfokus untuk menangani aspek kognitif dari depresi mengalami perkembangan yang cukup pesat dalam literatur ilmiah.

Hal yang perlu dipertimbangkan adalah, sudah terdapat banyak intervensi yang diteliti berfokus pada pengurangan gejala-gejala penyakit dengan menantang pola pikir yang maladaptif. Dalam literatur ilmiah, terdapat tidak terlalu banyak studi yang meneliti efektivitas dari intervensi psikologis yang mempromosikan pendekatan yang berpusat pada peningkatan emosi positif dalam populasi penderita masalah psikologis, yang pada saat yang sama, berpotensi menolong penderita kanker untuk maju meraih kehidupan yang bermakna sesuai dengan nilai kehidupan mereka masing-masing (Feros, Lane, Ciarrochi, \& Blackledge, 2013). Hal tersebut juga berlaku di Indonesia dalam hal kurangnya literatur ilmiah yang membahas topik tersebut.

Perkembangan literatur ilmiah psikologi yang berfokus pada bidang psikologi positif telah semakin meningkat selama beberapa dekade terakhir (Seligman \& Csikzenmihalyi, 2000). Salah satu aspek perkembangan tersebut adalah adanya perpindahan dari disease model yang berfokus pada penurunan symptom psikopatologi kepada aliran psikologi positif yang berfokus pada aspekaspek positif manusia, seperti kebahagiaan, kesejahteraan (well-being), dan pertumbuhan atau kemajuan pribadi (flourishing). Pergeseran fokus tersebut memicu para ahli untuk mengembangkan berbagai jenis intervensi baru yang tidak hanya berfokus untuk menghilangkan masalah saja, namun juga sekaligus untuk membuat hidup individu menjadi lebih bahagia dan bermakna.

Salah satu variabel dalam bidang psikologi positif yang telah ditemukan berkaitan erat dengan beberapa aspek well-being dan kesehatan mental adalah rasa syukur atau gratitude (Watkins, 2014). Penelitian tentang intervensi klinis berbasis gratitude telah menunjukkan hasil yang 
menjanjikan dalam mengembangkan fungsi positif kehidupan dan well-being, serta menangani masalah-masalah psikologis, melebihi variabel-variabel seperti optimisme, harapan, dan belas kasihan (compassion) (Emmons \& McCullough, 2013).

Secara spesifik, gratitude telah diteliti secara ilmiah dari sudut pandang aspek emosi individu dengan meminta mereka untuk mengumpulkan rasa syukur tersebut secara sadar melalui tugas gratitude journaling (Emmons \& McCullough, 2003). Sebagian besar penelitian yang mengkaji intervensi gratitude melibatkan partisipan penelitiannya untuk mengingat kembali peristiwaperistiwa kehidupan mereka di masa lalu (memory recollection) yang dapat memicu kondisi rasa syukur. Literatur telah menunjukkan bahwa kondisi kesehatan dan mood seseorang dapat membaik ketika kondisi rasa syukur dipicu dengan cara tersebut.

Manfaat dari variabel gratitude kembali ditunjukkan dalam penelitian lain yang membandingkan efektivitas dari lima jenis intervensi yang berbeda yang memiliki hipotesis bahwa jenis intervensi tersebut dapat meningkatkan kebahagiaan personal dan mengurangi tingkat depresi (Seligman, Steen, Park, \& Peterson, 2005). Studi-studi tersebut memberikan sebuah informasi berharga, yakni gratitude atau thankfulness merupakan sebuah variabel yang dapat dilatih dan ditingkatkan sebagai hasil dari intervensi.

Gratitude journal dipilih sebagai topik penelitian karena dua alasan. Pertama, aktivitas menulis melibatkan aktivitas kognitif tingkat lanjut yang berupaya untuk mengintegrasikan aspek-aspek pikiran, makna kata, dan menuangkannya dalam bentuk tulisan. Hal ini diduga dapat menangani aspek kognitif yang maladaptif sebagai akibat dari depresi (Emmons \& McCullough, 2013). Kedua, gratitude journal merupakan sebuah aktivitas yang sederhana, tidak membutuhkan energi kognitif yang tinggi, dapat dilakukan oleh siapapun yang dapat menulis, dan dapat dilakukan di mana saja dan kapan saja. Hal-hal tersebut dapat menjadi alasan utama dipilihnya jenis intervensi ini terhadap pasien kanker yang kemungkinan besar mengalami kesulitan bergerak dan memiliki energi rendah sebagai akibat dari penyakit kanker.

Aspek-aspek gratitude journaling di atas juga dapat digunakan untuk mengevaluasi salah satu karakteristik mood depresif, yakni bersifat fluktuatif dan context specific (Peeters, Berkhof, Delespaul, Rottenberg, \& Nicolson, 2006). Meskipun sifat depresi yang fluktuatif telah didokumentasi secara konsisten dalam literatur ilmiah, literatur masih memiliki informasi yang sedikit mengenai bagaimana depresi dapat mempengaruhi dinamika mood dalam keseharian penderita (Peeters et al., 2006). Studi oleh Peeters et al. (2006) menemukan adanya perbedaan tingkat emosi negatif yang menjadi bagian depresi yang signifikan antara kelompok individu dengan depresi klinis dan kelompok kontrol.

Akan tetapi, penelitian yang serupa belum dilakukan pada kelompok populasi depresi yang memiliki sakit fisik serius yang berada di luar kendali penderitanya. Gratitude journal, dengan karakteristiknya yang dapat dikerjakan kapan saja, dapat dimodifikasi oleh peneliti dengan menggunakan Ecological Momentary Sampling (Diary Sampling) untuk mengkaji aspek mood depresif yang fluktuatif, yang hasil evaluasinya dapat berpotensi memberikan informasi berharga dalam proses penyusunan intervensi yang melibatkan waktu dan konteks harian. Studi ini akan mengumpulkan data self-report gejala depresif secara real-time dalam keseharian partisipan

Tujuan dari penelitian ini adalah untuk memeriksa penerapan dari gratitude journal untuk mengurangi gejala depresif pada penderita kanker. Penelitian ini juga bertujuan untuk mengevaluasi aspek gejala depresif yang cenderung fluktuatif, serta memeriksa protective factors 
yang berpotensi untuk mengurangi gejala depresif pada partisipan. Hipotesis pertama penelitian ini adalah pasien kanker dengan masalah depresi akan mengalami pengurangan gejala-gejala depresi dalam bentuk penurunan skor BDI-2 setelah diberikan intervensi Gratitude Journal. Hipotesis kedua memprediksikan adanya perbedaan skor gejala depresif yang bermakna di antara tiga perlakuan (timepoint) yang berbeda, di mana kelompok Pagi dan Malam hari memiliki skor gejala depresif daripada kelompok Siang-Sore. Kemudian, hipotesis ketiga memprediksikan bahwa Pasien kanker dengan masalah depresi akan mengalami kenaikan rasa syukur dalam bentuk peningkatan skor GQ-6 setelah diberikan intervensi Gratitude Journal.

\section{METODE}

Enam partisipan wanita dengan berusia antara 35 sampai 56 tahun $(\overline{\mathrm{x}}=44.83)$ dengan diagnosis kanker dan gejala depresif berhasil direkrut dalam penelitian ini. 5 dari 6 partisipan masih bekerja sebagai karyawan (1 orang menetap sebagai ibu rumah tangga), dan 2 dari 6 partisipan masih berada dalam masa perawatan medis (4 orang berada dalam masa kontrol rutin). Kriteria depresi partisipan akan diukur dengan menggunakan The Beck Depression Inventory-II (BDI-II). Individu dengan skor di atas 0 (setidaknya terdapat gejala depresif meskipun tidak mencapai tahapan depresi klinis) memenuhi syarat untuk menjadi bagian dari penelitian ini. Partisipan yang berusia di bawah 12 tahun tidak dilibatkan dalam studi ini, karena partisipan berusia remaja awal memiliki kemungkinan untuk belum memiliki kapasitas kognitif yang diperlukan untuk menunjukkan atau mengekspresikan gejala depresif seperti orang dewasa (Hankin, Abramson, \& Siler, 2001). Teknik pengambilan sambil yang digunakan adalah non-probability dengan pendekatan purposive sampling. Peneliti bekerjasama dengan pihak rumah sakit untuk memperoleh partisipan penelitian yang sesuai dengan kriteria inklusi yang telah ditentukan. Ketika calon partisipan telah ditentukan, peneliti akan menghampiri setiap calon partisipan untuk melakukan proses penyaringan peserta penelitian (i.e., mengisi kuisioner pretest depresi) untuk memastikan bahwa calon partisipan memenuhi kriteria yang telah ditentukan. Untuk melihat data demografis partisipan, dapat mengacu pada Tabel 1.

Dalam hal pengambilan data, penelitian ini akan menggunakan pendekatan mixed method, yakni sebuah pendekatan gabungan antara kuantatif dan kualitatif (Creswell, 2009). Pendekatan mixed method yang akan digunakan dalam penelitian ini adalah sequential explanatory design, yang melibatkan dua fase penelitian. Fase pertama adalah pengumpulan data secara kuantitatif, yang kemudian akan diikuti dengan fase kedua, yakni pengumpulan data kualitatif untuk menjelaskan dan menginterpretasi data kuantitatif yang telah dikumpulkan. Salah satu tujuan dari pendekatan ini adalah untuk mengidentifikasi dan menjelaskan variabel penelitian yang ingin dieksplorasi lebih lanjut.

Tabel 1 Data Demografis Partisipan Penelitian

\begin{tabular}{|c|c|c|c|c|c|c|c|}
\hline $\begin{array}{l}\text { Nama } \\
\text { (Inisial) }\end{array}$ & $\begin{array}{c}\text { Jenis } \\
\text { Kelamin }\end{array}$ & $\begin{array}{l}\text { Usia } \\
\text { (th) }\end{array}$ & Pekerjaan & Agama & $\begin{array}{c}\text { Jenis } \\
\text { Kanker }\end{array}$ & Status & $\begin{array}{c}\text { Thn. } \\
\text { Diagnosis }\end{array}$ \\
\hline B & Perempuan & 35 & Karyawati & Islam & Limfoma Non-Hodgkin & $\begin{array}{c}\text { Dalam } \\
\text { Perawatan }\end{array}$ & 2016 \\
\hline $\mathrm{N}$ & Perempuan & 45 & PNS & Islam & Lambung & $\begin{array}{c}\text { Masa } \\
\text { Kontrol }\end{array}$ & 2017 \\
\hline $\mathrm{Y}$ & Perempuan & 56 & Karyawati & Islam & Payudara & $\begin{array}{c}\text { Masa } \\
\text { Kontrol }\end{array}$ & 2012 \\
\hline A & Perempuan & 49 & $\begin{array}{c}\text { Ibu Rumah } \\
\text { Tangga }\end{array}$ & Kristen & Payudara & $\begin{array}{c}\text { Masa } \\
\text { Kontrol }\end{array}$ & 2015 \\
\hline $\mathrm{L}$ & Perempuan & 45 & Karyawati & Islam & Payudara & $\begin{array}{c}\text { Masa } \\
\text { Kontrol }\end{array}$ & 2012 \\
\hline S & Perempuan & 39 & $\begin{array}{l}\text { P. Rumah } \\
\text { Tangga }\end{array}$ & Islam & Payudara & $\begin{array}{c}\text { Dalam } \\
\text { Perawatan }\end{array}$ & 2017 \\
\hline
\end{tabular}


Partisipan diinstruksikan untuk secara aktif menuliskan satu hal yang menimbulkan rasa bersyukur beserta dengan alasannya. Instruksi aktivitas adalah sebagai berikut, yang diadaptasikan dari penelitian gratitude journal oleh Emmons dan McCullough (2003): "Pada saat ini, mari arahkan fokus sejenak pada hal-hal positif yang telah Anda terima atau miliki dalam hidup ini. Hal-hal tersebut dapat merupakan hal sederhana seperti orang-orang yang masih bersama-sama dengan Anda, kemampuan atau talenta pribadi, kenikmatan sarapan yang Anda santap, momen ketika menikmati keindahan alam, ataupun kebaikan kecil yang diterima dari orang lain. Anda mungkin biasanya tidak mempertimbangkan hal-hal tersebut sebagai suatu berkah yang harus disyukuri, mari pada saat ini kita berusaha secara aktif untuk melakukan aktivitas tersebut. Ambillah waktu sejenak untuk betul-betul menikmati hal atau momen berkah tersebut, renungkan betapa berharganya pengalaman-pengalaman besar atau kecil itu, kemudian ekspresikan rasa syukur itu dalam bentuk tulisan."

Setelah aktivitas selesai dilakukan, partisipan diinstruksikan untuk mengisi sembilan pertanyaan kuisioner BDI-II (dimensi kognitif) setiap setelah penulisan gratitude journal. Aktivitas ini dilakukan sejumlah tiga kali dalam sehari, yakni pada saat pagi, siang-sore, dan malam hari. Aktivitas ini memiliki durasi dua minggu. Jadwal penulisan gratitude journal dan pengisian kuisioner adalah sebagai berikut: (1) Pagi hari: Pukul 07.00 - 10.00; (2) Siang-Sore hari: Pukul 13.00 - 16.00; dan (3) Malam hari: Pukul 19.00 - 22.00. Selama masa pengambilan data, peneliti akan memberikan reminder sebanyak tiga kali sehari pada pukul 07.00, 13.00, dan 19.00, untuk mengingatkan partisipan melakukan aktivitas dengan cara membentuk grup whatsapp penelitian di mana reminder akan diberikan.

Untuk memperoleh data mengenai tingkat fluktuasi emosi, studi ini akan menggunakan Experience Sampling Methods (ESM; Csikszentmihalyi \& Larson, 1987) atau Ecological Momentary Assessment (EMA; Stone \& Shiffman, 1994) yang adalah sebuah pendekatan dalam pengambilan data penelitian yang memiliki fokus yang sama, yaitu self-report pada waktu yang telah ditentukan.

\section{Instrument Penelitian}

The Beck Depression Inventory-II (BDI-II) yang dipelopori oleh Beck dan timnya (Beck, Steer, \& Brown, 1996). BDI-II mengandung dua dimensi utama, yakni dimensi somatik/afektif dan kognitif. Terdapat sembilan butir pertanyaan yang mengukur dimensi kognitif, dan 12 butir pertanyaan yang mengukur dimensi somatik/afektif. 21 butir item tersebut akan dijawab dalam skala 0 sampai 3, dengan " 0 " mengindikasikan bahwa partisipan tidak merasakan pernyataan butir item tersebut sama sekali dan "3" menyatakan bahwa partisipan sangat merasakan pernyataan butir item yang bersangkutan. BDI-II ini sendiri dinilai cocok untuk digunakan pada partisipan berusia 13 tahun ke atas. Hasil skor akan dikategorikan ke dalam salah satu dari empat kelompok intensitas gejala depresif yang dapat dilihat pada Tabel 2 .

Tabel 2 Interpretasi dari Skor Alat Ukur BDI-II

\begin{tabular}{cc}
\hline Total Score & Relative Severity \\
\hline $0-13$ & Minimal \\
$14-19$ & Mild \\
$20-28$ & Moderate \\
$29-63$ & Severe \\
\hline
\end{tabular}

Variabel trait gratitude, yaitu gratitude disposition akan diukur dengan menggunakan The Gratitude Questionnaire-Six Item Form (GQ-6) oleh McCullough, Emmons, dan Tsang (2002). 
Skala ini terdiri dari 7 pilihan, dimulai dari sangat setuju hingga setuju dengan skoring: Sangat Setuju $=7$, Setuju $=6$, Sedikit Setuju $=5$, Netral $=4$, Sedikit Tidak Setuju $=3$, Tidak Setuju $=2$, Sangat Tidak Setuju = 1. Pada skala GQ-6, skoring positif berlaku untuk item nomor 1, 2, 4, dan 5, sedangkan hasil akan menjadi reversed untuk butir nomor 3 dan 6 karena merupakan butir negatif. Seluruh skor kemudian dijumlahkan, yang kemudian menghasilkan skor antara 6-42.

Berdasarkan sampel 1.224 orang dewasa yang berpartisipasi dalam penelitian oleh McCullough, Emmons, dan Tsang (2002) sebagai bagian dari studi pada website Spirituality and Health, ditemukan norma untuk menginterpretasikan hasil dari GQ-6. Jika skor akhir adalah 35 dari 42, maka partisipan berada pada persentil ke-25 atau memiliki skor lebih tinggi dari $25 \%$ grup norma. Jika skor adalah 38 dari 42, maka partisipan berada pada persentil ke-50 atau menghasilkan skor lebih tinggi dari 50\% grup norma. Jika skor adalah 41 dari 42 , maka partisipan berada pada persentil ke-75 atau memiliki skor lebih tinggi dari $75 \%$ grup norma. Terakhir, jika partisipan menghasilkan skor akhir sempurna (42), maka partisipan berada pada skor $13 \%$ teratas dari sampel 1.224 orang dewasa.

Untuk penelitian ini, peneliti melakukan proses adaptasi GQ-6 ke dalam Bahasa Indonesia. Untuk menguji validitas, peneliti telah menerjemahkan setiap butir item dari GQ-6, kemudian meminta expert judgement dari tiga dosen senior Universitas Tarumanagara. Ketiga dosen tersebut telah menyatakan bahwa terjemahan setiap butir item telah memadai dan dapat digunakan. Setelah itu, peneliti memperoleh data inter-item consistency atau Cronbach alpha sebesar .65, yang dapat dinilai memiliki konsistensi antar-item yang acceptable. Data tersebut diperoleh dari 29 mahasiswa paskasarjana psikologi profesi, Universitas Tarumanagara.

Pendekatan kualitatif dari studi ini akan menggunakan pendekatan coding oleh Saldaña (2009). Peneliti akan melakukan analisis tematik dengan memeriksa konten tulisan ucapan syukur yang terdapat dalam gratitude journal seluruh peserta penelitian untuk mengidentifikasi tema-tema yang berpotensi menjadi protective factors terhadap gejala depresif.

\section{HASIL}

Untuk memeriksa ada tidaknya penurunan gejala depresif yang signifikan, uji statistik nonparametrik Wilcoxon Signed Rank Test digunakan pada skor pretest-posttest BDI-II partisipan. Metode statistik yang sama digunakan untuk menguji ada tidaknya kenaikan yang bermakna pada skor pretest-posttest trait gratitude dari GQ-6. Terakhir, untuk memeriksa adanya perbedaan yang signifikan dalam gejala depresif pada tiga kondisi waktu yang berbeda, uji non-parametrik Kruskall-Wallis pada skor BDI-II (dimensi kognitif) dan tiga time points dilakukan. Informasi deskriptif hasil pretest-posttest partisipan secara keseluruhan dapat dilihat pada Tabel 2.

Tabel 3 Hasil Pretest dan Posttest GQ-6 dan BDI-II Seluruh Partisipan

\begin{tabular}{ccccc}
\hline \multirow{2}{*}{ Partisipan } & \multicolumn{2}{c}{ GQ-6 } & \multicolumn{2}{c}{ BDI-II } \\
\cline { 2 - 5 } & Pretest & Posttest & Pretest & Posttest \\
\hline B & 35 & 39 & 15 & 12 \\
N & 41 & 42 & 7 & 1 \\
Y & 42 & 42 & 17 & 8 \\
A & 41 & 41 & 7 & 3 \\
L & 39 & 41 & 6 & 1 \\
S & 42 & 42 & 68 & 26 \\
Total & 240 & 247 & 58 - Six Item Form; BDI-II = The Beck Depression Inventory-II
\end{tabular}




\section{Analisis Kuantitatif}

Gejala depresi. Pada tahap pretest maupun posttest, terdapat empat partisipan yang tidak memiliki gejala depresif yang signifikan (berdasarkan alat ukur BDI-II), namun keempat partisipan tersebut menunjukkan adanya penurunan skor. Untuk menguji asumsi normalitas pada variabel gejala depresif, test normalitas Shapiro-Wilk dilakukan. Uji normalitas mendemonstrasikan bahwa data pretest dan posttest dari gejala depresif tidak terdistribusi dengan normal ( $\mathrm{p}<.05)$, sehingga uji statistik non-parametrik Wilcoxon Signed Rank Test digunakan untuk memeriksa ada tidaknya perbedaan bermakna antara kedua kelompok skor. Hasil uji perbedaan menunjukkan adanya perbedaan yang bermakna antara kelompok skor pretest dan posttest, $\mathrm{z}=-2.207, p<.05$, twotailed.

Gratitude trait. Test Shapiro-Wilk digunakan untuk menguji asumsi normalitas pada data variabel trait gratitude. Uji normalitas mengindikasikan bahwa data pretest dan posttest dari trait gratitude tidak terdistribusi dengan normal $(p<.05)$, sehingga uji statistik non-parametrik Wilcoxon Signed Rank Test digunakan untuk memeriksa adanya perbedaan signifikan antara kedua kelompok skor. Hasil uji perbedaan menunjukkan tidak adanya perbedaan yang bermakna antara kelompok skor pretest dan posttest, $\mathrm{z}=-1.604, p=.109$, two-tailed.

Fluktuasi gejala depresi. Test Shapiro-Wilk untuk menguji asumsi normalitas dilakukan pada variabel gejala depresif (dimensi kognitif) pada data dengan tiga perlakuan (time-point) yang berbeda. Uji normalitas menunjukkan bahwa data tidak terdistribusi dengan normal $(p<.001)$. Distribusi data tetap tidak normal meskipun telah diberikan berbagai bentuk transformasi data (i.e., $\log 10$, square root, rank case, inverse $d f$ ), sehingga uji statistik non-parametrik Kruskall Wallis digunakan untuk melihat apakah perbedaan perlakuan atau timepoint memberikan pengaruh yang bermakna terhadap gejala depresif (dimensi kognitif) pada partisipan. Hasil tes Kruskall Wallis menunjukkan tidak ada perbedaan yang bermakna $\left(\chi^{2}=.537, p=.765, \mathrm{df}=2\right)$ di antara tiga kondisi waktu yang berbeda (Pagi, Siang-Sore, Malam), sehingga tidak dilanjutkan dengan analisis posthoc untuk melihat letak perbedaan antar kelompok perlakuan.

\section{Analisis Kualitatif (Coding)}

Berdasarkan analisis tematik yang telah dilakukan, peneliti menemukan empat tema, antara lain: (1) Menghargai kesehatan fisik dan menjadi produktif, (2) koneksi sosial yang bermakna, (3) menikmati momen sederhana dalam keseharian (mindfulness), dan (4) spiritualitas dan religiusitas yang bermakna.

\section{Menghargai kesehatan fisik dan menjadi produktif.}

Salah satu hal yang paling sering diungkapkan oleh para partisipan penelitian ketika menuliskan alasan bersyukur adalah mengenai apresiasi mereka terhadap kesehatan fisik. Partisipan cenderung mensyukuri aspek-aspek tubuh yang normal dimiliki oleh individu yang memiliki tubuh yang sehat, seperti dapat bernafas, memiliki stamina yang normal, dan masih dapat bangun pada pagi hari. Partisipan juga menjadi mampu untuk menghargai aspek kesehatan fisik yang normal dirasakan bagi mereka yang tidak pernah sakit kanker, dan juga menghargai kemampuan untuk dapat beraktivitas dalam kesehariannya. Contohnya adalah, "Tetap mengucap syukur kepada Tuhan karena masih diberikan tubuh yang sehat dan kuat. Jadi aku bisa keliling tanpa merasa lelah." Selain itu, partisipan juga melaporkan adanya kenaikan rasa apresiasi terhadap kondisi tubuh yang baik setelah melewati berbagai gejala fisik yang tidak nyaman sebagai akibat dari intervensi medis maupun sakit kanker itu sendiri, "Tadi pagi sempatkan untuk jalan pagi, terasa lebih segar." 


\section{Koneksi sosial yang bermakna.}

Hal kedua yang dapat ditemukan pada seluruh catatan ucapan syukur partisipan adalah mereka memiliki lingkaran sosial yang suportif dan selalu mendukung kondisi kesehatan mereka, baik dalam lingkaran keluarga maupun persahabatan. Hal ini dapat mengindikasikan bahwa partisipan mulai menyadari tentang aspek penting kehidupan mereka setelah melewati pengalaman yang berpotensi mengakibatkan kematian, terutama bagi mereka yang masih berada dalam masa perawatan. Dalam gratitude journal, partisipan juga menuliskan pertemuan sederhana dengan keluarganya yang menimbulkan rasa syukur, "Bersyukur badan oke, keluarga kumpul dan bisa makan. Bersyukur bertemu keponakan."

\section{Menikmati momen sederhana dalam keseharian (mindfulness).}

Temuan ketiga adalah adanya penulisan di mana partisipan memperhatikan hal-hal kecil, yang pada saat yang sama menimbulkan rasa syukur. Hal ini merupakan bagian dari praktek mindfulness. Mindfulness itu sendiri memiliki banyak konseptualisasi dalam literatur ilmiah, namun secara keseluruhan, mindfulness dapat didefinisikan sebagai kondisi ketika seseorang memperhatikan dan merasakan segala informasi sensoris yang ada di sekitarnya pada momen tersebut tanpa berupaya untuk menilai baik-buruknya pengalaman itu (Brown, Ryan, \& Creswell, 2007). Sebagai contoh, terdapat partisipan yang melaporkan momen yang berhubungan dengan alam, "Bersyukur atas hujan hampir setengah hari ini, walaupun jadi lembab, tapi tanah terguyur dan polusi hilangan dikit. Bersyukur bisa pegang puppies dan ibunya, tapi mereka kayak boneka kecil setelapak tangan, kurang oke, but grateful."

\section{Spiritualitas dan religiusitas sebagai pemicu kebahagiaan.}

Dalam studi ini, partisipan berhasil mengungkapkan pengalaman bersyukur yang berkaitan dengan hal-hal yang bersifat spiritual dan religius. Dalam literatur ilmiah, definisi aspek spiritual dan religius terkadang digunakan secara bersamaan atau memiliki makna yang relatif serupa (Himelhoch \& Njie-Carr, 2016). Akan tetapi, untuk memperoleh insight yang lebih spesifik, studi ini akan menggunakan dua terminologi tersebut sebagai definisi yang memiliki makna yang berbeda. Spiritualitas mengacu pada pengalaman dan perasaan internal individu yang bersifat transendens atau supranatural. Religiusitas memiliki makna yang serupa, namun bersifat spesifik atau dibatasi oleh praktek dan ritual yang telah disepakati atau ditentukan oleh doktrin maupun institusi agama yang berkaitan (Himelhoch \& Njie-Carr, 2016). Dalam studi ini, contoh rasa syukur yang diungkapkan yang berkaitan dengan hal-hal di atas adalah, "Pagi ini disyukuri dengan berterimakasih kepada Sang Pencipta karena masih diberikan umur bisa menikmati matahari pagi. Secangkir kopi dan sarapan roti. Entah kenapa teringat orang-orang yang sudah pergi lebih dulu menghadap Sang Pencipta. Betapa hidup ini terasa singkat. Sangat-sangat bersyukur masih diberikan umur panjang dan dapat kesempatan berobat akan sakitku.”

\section{DISKUSI}

Tujuan utama dari penelitian ini adalah untuk mengetahui efektivitas dari gratitude journal terhadap penurunan gejala depresif pada penderita kanker. Pada saat yang sama, penelitian ini juga bertujuan untuk mengevaluasi aspek gejala depresif yang cenderung fluktuatif, serta memeriksa protective factors yang berpotensi untuk mengurangi gejala depresif pada partisipan. Hipotesis pertama yang memprediksikan adanya penurunan gejala depresif setelah dilakukannya aktivitas penelitian berhasil dipenuhi. Namun, hipotesis kedua yang memprediksikan adanya perbedaan gejala depresif bermakna di antara tiga timepoints tidak berhasil dipenuhi. Terakhir, hipotesis ketiga juga tidak dipenuhi, yakni tidak terdapat kenaikan bermakna pada skor trait gratitude partisipan setelah aktivitas penelitian selesai. 
Penurunan skor gejala depresif secara signifikan merupakan hasil penelitian yang konsisten dengan studi-studi sebelumnya (Emmons \& McCullough, 2003, Studi 1; Emmons \& McCullough, 2013; Seligman, Steen, Park, \& Peterson, 2005). Berdasarkan teori The Hopelessness Theory of Depression (Abramson, Metalsky, \& Alloy, 1989) dan Beck's Depression Cognitive Triad (Beck, 1967), seseorang dapat mengembangkan kecenderungan untuk menjadi depresi ketika mereka memiliki negative inferential style, yakni sebuah pola pikir yang memandang peristiwa kehidupan secara lebih negatif dibandingkan dengan mereka yang tidak memilikinya. Dalam penelitian ini, sakit kanker merupakan peristiwa hidup negatif yang signifikan.

Secara teoritis, aktivitas gratitude journal dapat melatih partisipan untuk mengembangkan sebuah perspektif baru yang lebih positif. Dengan kata lain, aktivitas ini mengajarkan patisipan untuk tidak berfokus pada peristiwa kehidupan negatif (yang tidak dapat dihindari), namun berfokus pada hal-hal dalam hidup yang dapat disyukuri. Individu dengan trait gratitude yang tinggi (seperti yang ada pada seluruh partisipan studi ini) tidak selalu memiliki keterampilan untuk mengekspresikan rasa syukur secara konkrit.

Gratitude journal melatih individu untuk dapat mengintegrasikan konten pikiran, makna semantik dari kata, dan mengungkapkannya dalam bentuk tulisan. Keterampilan-keterampilan tersebut membutuhkan aktivitas kognitif tingkat tinggi, yang kemudian diarahkan pada hal-hal yang dapat disyukuri. Gratitude journal memberikan sebuah frame of reference yang baru bagi partisipan yang memampukan individu untuk menyadari dan mengatribusikan emosi positif pada peristiwa kehidupan positif yang mereka alami.

Dengan kata lain, aktivitas berbasis gratitude dapat melatih kapabilitas kognitif, fleksibilitas atau keluasan proses berpikir, serta menghambat proses emosi negatif. Hal inilah yang diduga dapat menurunkan gejala depresif pada partisipan penelitian. Maka, hasil penelitian ini menunjukkan adanya kemungkinan bahwa gratitude journal dapat menangani aspek kognitif depresi yang maladaptif, sehingga berkaitan dengan turunnya skor gejala depresif pada partisipan. Hasil ini konsisten dengan studi oleh Emmons \& McCullough, 2013).

Tidak adanya perbedaan skor gejala depresif pada tiga waktu yang berbeda (pagi, siang-sore, dan malam hari) mencerminkan tidak adanya mood depresif yang fluktuatif pada partisipan. Hasil ini tidak konsisten dengan penelitian oleh Peeters, Berkhof, Delespaul, Rottenberg, dan Nicolson (2006) yang menemukan adanya perbedaan tingkat emosi negatif yang memicu depresi antara kelompok partisipan yang memiliki depresi klinis dan kelompok kontrol. Hal ini dapat disebabkan karena perbedaan intensitas gejala depresif yang dimiliki oleh studi tersebut. Partisipan penelitian dalam studi Peeters et al. (2006) memiliki diagnosis Major Depressive Disorder (MDD), sedangkan partisipan dalam studi ini hanya mengambil partisipan yang memiliki gejala depresif saja tanpa adanya diagnosis MDD.

Selain itu, seluruh partisipan dalam penelitian ini telah menunjukkan trait gratitude yang tinggi dan melakukan aktivitas gratitude journal sebelum pengambilan data skor depresif dilakukan. Dengan kata lain, dalam studi ini, gejala depresif pada partisipan diukur setelah mereka melakukan aktivitas penelitian yang secara teoritis dapat meningkatkan emosi positif dan menurunkan kemungkinan adanya gejala depresif. Hal ini kembali dikonfirmasi oleh adanya penurunan skor gejala depresif yang bermakna setelah masa aktivitas selesai dilakukan.

Dengan adanya aktivitas yang memberikan instruksi untuk bersyukur hampir sepanjang hari, terdapat kemungkinan bahwa meskipun fluktuasi gejala depresif memang ada dalam diri 
partisipan, fluktuasi tersebut berhasil diturunkan intensitasnya sebagai akibat dari aktivitas gratitude journal. Akan tetapi, asumsi tersebut masih belum dapat ditegakkan tanpa adanya follow-up study yang secara khusus menginvestigasi prediksi itu.

Seperti yang telah dipaparkan sebelumnya, studi ini menemukan bahwa seluruh partisipan penelitian sudah memiliki trait gratitude yang tinggi dari sebelum dilakukannya aktivitas gratitude journal, yang pada saat yang sama mengalami penurunan skor gejala depresif secara signifikan. Selain dari yang telah dijelaskan perihal aktivitas menulis dapat melatih partisipan untuk mengungkapkan rasa syukurnya secara konkrit, peneliti berupaya untuk memeriksa konten gratitude journal dan menemukan empat tema yang diduga berperan penting dalam penurunan skor gejala depresif, antara lain: (1) menghargai kesehatan fisik dan menjadi produktif, (2) koneksi sosial yang bermakna, (3) menikmati momen sederhana dalam keseharian (mindfulness), dan (4) spiritualitas dan religiusitas yang bermakna.

Seluruh partisipan mengungkapkan rasa syukurnya perihal tidak adanya rasa sakit dan ketika mampu bekerja atau produktif kembali. Jika dikaitkan dengan penelitian oleh Effendy et al. (2014), hasil analisis kualitatif tersebut dapat dipahami. Penderita kanker cenderung mengembangkan depresi karena ketakutan akan rasa sakit, kehilangan kemampuan untuk menjadi mandiri, dan perasaan tidak berdaya untuk mengubah keadaan. Penderita kanker juga cenderung merasa bahwa masa depannya tidak dapat diprediksi, sehingga dapat memicu emosi negatif. Partisipan dalam penelitian ini justru mensyukuri hal-hal yang bertolak belakang dengan hasil studi oleh Effendy et al. (2014).

Sebagai contoh, partisipan yang masih berada dalam masa perawatan mengungkapkan rasa syukurnya ketika terdapat sesi kemoterapi yang keluhan fisiknya (e.g., sakit, mual) lebih sedikit dibandingkan dengan sebelumnya. Ketika partisipan berfokus pada hal kecil yang berkaitan dengan kelegaan dari keluhan fisik, mereka melaporkan adanya penurunan gejala depresif. Selain itu, partisipan yang sudah ada dalam masa kontrol secara berulang-ulang mensyukuri kemampuan mereka untuk kembali produktif (e.g., bekerja, melayani di gereja), sehingga tidak heran mereka memiliki trait gratitude yang tinggi yang berpotensi melindungi mereka dari emosi negatif pemicu depresi.

Partisipan juga melaporkan rasa syukur karena berada di dalam kelompok sosial yang bermakna, seperti keluarga dan komunitas yang suportif. Literatur ilmiah telah menunjukkan secara terusmenerus tentang social support sebagai protective factor yang baik dalam mengurangi gejala depresif individu (Grunebaum et al., 2010; Khalil \& Abed, 2014). Sebagai contoh, studi oleh Khalil dan Abed (2014) berhasil menemukan bahwa kualitas hubungan pertemanan yang tidak konstruktif dapat meningkatkan resiko bunuh diri pada partisipan dewasa dengan depresi. Dalam penelitian ini, partisipan dengan jelas mengungkapkan bahwa mereka selalu didukung oleh anggota keluarga dan teman masa kecil, sehingga memberikan indikasi bahwa mereka memiliki lingkungan sosial yang baik, yang diduga dapat mencegah memburuknya gejala depresif.

Tema berikutnya yang ditemukan adalah adanya aspek mindfulness dalam konten tulisan ucapan syukur partisipan. Temuan ini konsisten dengan studi kualitatif oleh O’Neill, McCaughan, Semple, dan Ryan (2018) mengenai pengalaman ayah yang menerima diagnosis kanker. Penelitian mereka menemukan setelah para ayah menerima diagnosis kanker, mereka menjadi lebih fokus pada masa kini, secara spesifik, menciptakan dan menikmati momen-momen sederhana dengan anak-anak mereka, seperti ketika makan bersama dengan anak. 
Salah satu karakteristik dari aspek kognitif individu yang mengalami depresi adalah adanya ruminasi, atau pemikiran yang berfokus pada "seandainya" atau masa lalu (Barlow \& Durand, 2015). Aktivitas gratitude journal pada dasarnya membawa seseorang untuk fokus dan merasakan informasi sensoris yang sedang dialami pada masa kini tanpa menilai baik-buruknya pengalaman tersebut (Brown, Ryan, \& Creswell, 2007). Dengan kata lain, gratitude journal juga dapat berfungsi untuk melatih partisipan dengan kecenderungan depresi untuk pindah dari pikiran yang berfokus pada masa lalu menjadi menikmati masa kini.

Terakhir, seluruh partisipan juga menuliskan ucapan syukur dengan tema yang berkaitan dengan spiritualitas dan religiusitas. Berbagai studi telah mendemonstrasikan pentingnya peranan kedua aspek tersebut dalam meningkatkan kesehatan mental dengan memberikan kebermaknaan dalam hidup seseorang, terutama bagi mereka yang berusia dewasa akhir (Atchley, 2006; Wink \& Dillon, 2008).

Snodgrass dan Sorajjakool (2011) juga berpendapat bahwa ketika seseorang mengalami "pelajaran" kehidupan yang sulit, terutama peristiwa kehidupan yang menyebabkan individu merasa nyawanya terancam (e.g., sakit, penuaan), individu tersebut akan cenderung memasuki masa transisi yang menyebabkan mereka menjunjung tinggi spiritualitas. Individu itu akan berusaha untuk menciptakan atau mencari makna kehidupan sebagai bentuk dari coping system, yang dapat menjadi protective factor terhadap emosi negatif.

Dalam studi ini, terdapat sebagian partisipan yang mengekspresikan spiritualitas mereka melalui agama yang dianut. Berdasarkan kajian literatur ilmiah mengenai dampak positif dari nilai religius pada partisipan yang menjunjung tinggi nilai religius, Noronha (2015) berpendapat bahwa pekerja klinis harus dapat mempertimbangkan nilai-nilai agama dan budaya yang dimiliki oleh partisipan supaya hubungan terapeutik yang baik dapat terbentuk. Tentu saja, hal tersebut tidak berlaku jika terdapat klien yang menganut pemahaman sekuler.

Terdapat beberapa kelemahan dalam penelitian ini. Pertama, dengan diambilnya sampel penelitian yang tidak memiliki diagnosis depresi secara tegas, hal ini menyebabkan hasil dari penelitian ini sulit untuk digeneralisir pada konteks yang spesifik, seperti pada konteks gangguan depresif secara klinis. Giollabhui et al. (2018) menjelaskan bahwa individu dengan depresi cenderung memiliki negative inferential style, yang berpotensi untuk memandang sebuah peristiwa dengan negatif. Dengan kata lain, penelitian ini tidak dapat mengambil konklusi secara tegas telah mengkaji efek gratitude journal dalam mempengaruhi perspektif kognitif negatif yang umumnya dimiliki oleh mereka yang memiliki gangguan depresi secara klinis.

Kedua, desain penelitian ini tidak memiliki kriteria inklusif mengenai tinggi atau rendahnya skor trait gratitude yang dimiliki individu. Dengan tidak adanya grup pembanding antara partisipan yang memiliki rasa syukur yang tinggi dengan yang rendah, sulit untuk menerima konklusi bahwa trait gratitude merupakan variabel yang berperan dalam menurunkan gejala depresif secara kausal. Dengan kata lain, terdapat kemungkinan adanya confounding variable yang tidak berada dalam jangkauan penelitian ini, yang justru berperan lebih signifikan terhadap turunnya skor gejala depresif partisipan.

Selain itu, penelitian ini juga tidak mengontrol faktor-faktor yang berpotensi untuk mempengaruhi hasil intervensi, seperti waktu sesi kemoterapi dan konsumsi obat-obatan para peserta penelitian. Terdapat kemungkinan bahwa penurunan skor gejala depresif pada partisipan merupakan pengaruh dari para partisipan yang sedang tidak menjalani masa kemoterapi atau efek dari obat- 
obatan yang sifatnya meringankan gejala sakit yang umum diberikan pada pasien bangsal paliatif. Akan tetapi, studi ini tidak dapat secara tegas mengkaji hal tersebut karena faktor-faktor medis tersebut tidak masuk dalam ruang lingkup desain penelitian.

Salah satu hal yang perlu dikaji lebih lanjut berdasarkan hasil penelitian ini adalah efektivitas gratitude journal untuk menurunkan gejala depresif pada individu dengan gejala depresif klinis yang serius. Hal tersebut dapat memberikan insight lebih lanjut mengenai keterkaitan antara ketidakberdayaan aspek kognitif yang umumnya dimiliki individu dengan depresi dan intervensi berbasis peningkatan emosi positif dan kualitas hidup.

\section{KESIMPULAN Dan SARAN}

Penelitian ini menunjukkan bahwa aktivitas gratitude journal dapat digunakan sebagai salah satu jenis intervensi yang dapat mengurangi gejala depresif pada penderita kanker. Aktivitas gratitude journal dapat diberikan sebagai intervensi komplementer yang mengiringi jenis intervensi kognitif lainnya, seperti CBT dan REBT karena tingkat kesulitan aktivitas yang relatif rendah dan dapat dilakukan di mana saja.

Studi ini juga kembali menegaskan hasil penelitian-penelitian sebelumnya mengenai aspek-aspek dalam kehidupan partisipan yang dapat melindugi mereka dari emosi negatif, seperti apresiasi terhadap tubuh yang sehat, koneksi sosial yang berharga, daya fokus untuk menikmati momen saat ini, serta nilai spiritual dan religius yang dianut oleh partisipan. Oleh karena itu, klinisian perlu mempertimbangkan hal-hal di atas untuk diintegrasikan dalam hubungan terapeutik demi meningkatkan emosi positif individu, terutama bagi mereka yang menjunjung tinggi nilai tersebut.

Penelitian dengan ecological momentary assessment di masa depan dapat menetapkan waktu pengambilan data yang lebih lama untuk memastikan ada tidaknya, signifikan maupun tidak signifikannya fluktuasi emosi depresif dalam diri seseorang. Dengan meningkatnya durasi penelitian, maka peneliti juga dapat memberikan konklusi yang lebih tegas mengenai dampak dari sebuah intervensi untuk menangani gejala maladaptif dalam diri seseorang. Penelitian di masa depan juga dapat merancang studi yang lebih komprehensif dengan adanya kontrol variabelvariabel yang diduga dapat mempengaruhi hasil akhir penelitian (e.g., obat-obatan).

Hasil penelitian ini dapat dijadikan acuan bagi pihak-pihak yang bekerja dalam keprofesian kesehatan, sosial, maupun keluarga yang mempunyai anggota keluarga dengan penderita kanker yang memiliki depresi, bahwa aktivitas yang sederhana memiliki potensi untuk menangani emosi negatif pada individu. Seperti yang telah dipaparkan di atas, para pekerja klinis juga perlu mempertimbangkan aspek-aspek yang membentuk diri klien, seperti nilai kebudayaan dan agama yang dianut supaya hubungan terapeutik yang baik dapat terbentuk

\section{UCAPAN TERIMA KASIH}

Penulis mengucapkan terima kasih yang sebesar-besarnya kepada pihak-pihak yang telah berkontribusi besar dalam penyelesaian dan penulisan studi ini, khususnya partisipan penelitian. Terima kasih juga kepada Rumah Sakit X atas izin yang diberikan untuk dapat melakukan penelitian serta bimbingan dari staff bagian paliatif. 


\section{REFERENSI}

Abramson, L. Y., Metalsky, G. I., \& Alloy, L. B. (1989). Hopelessness depression: A theory-based subtype of depression. Psychological Review, 96(2), 358-372.

Atchley, R. C. (2006). Continuity, spiritual growth, and coping in later adulthood. Journal of Religion, Spirituality and Aging, 18(2-3), 19-29.

Barlow, D. H., \& Durand, V. M. (2015). Abnormal psychology: An integrative approach., 7th ed. Belmont, CA, US: Cengage Learning.

Beck, A. T. (1967). Depression: Clinical, experimental and theoretical aspects. New York: Harper \& Row

Beck, A. T., Steer, R. A., \& Brown, G. K. (1996). Manual for the Beck Depression Inventory-II. San Antonio, TX: Psychological Corporation.

Brown, K. W., Ryan, R. M., \& Creswell, J. D. (2007). Mindfulness: Theoretical foundations and evidence for its salutary effects. Psychological Inquiry, 18, 211-237. doi:10.1080/10478400701598298

Chintamani, Gogne, A., Khandelwal, R., Tandon, M., Jain, S., Kumar, Y., \& ... Saxena, S. (2011). The correlation of anxiety and depression levels with response to neoadjuvant chemotherapy in patients with breast cancer. JRSM Short Reports, 2(3), 15. doi:10.1258/shorts.2010.010072

Creswell, J. W. (2009). Research design: Qualitative, quantitative, and mixed methods approaches (3rd ed.). Los Angeles: Sage Publications, Inc.

Effendy, C., Vissers, K., Osse, B. P., Tejawinata, S., Vernooij-Dassen, M., \& Engels, Y. (2014). Comparison of problems and unmet needs of patients with advanced cancer in a European country and an Asian country. Pain Practice: The Official Journal of World Institute of Pain, 15(5), 433-440. doi:10.1111/papr.12196

Emmons, R. A., \& McCullough, M. E. (2003). Counting blessings versus burdens: an experimental investigation of gratitude and subjective well-being in daily life. Journal of Personality and Social Psychology, 84(2), 377-389.

Emmons, R. A., \& Stern, R. (2013). Gratitude as a psychotherapeutic intervention. Journal of Clinical Psychology, 69(8), 846-855. https://doi.org/10.1002/jclp.22020

Feros, D. L., Lane, L., Ciarrochi, J., \& Blackledge, J. T. (2013). Acceptance and Commitment Therapy (ACT) for improving the lives of cancer patients: a preliminary study. PsychoOncology, 22(2), 459-464.

Grunebaum, M. F., Galfalvy, H. C., Mortenson, L. Y., Burke, A. K., Oquendo, M. A., \& Mann, J. J. (2010). Attachment and social adjustment: relationships to suicide attempt and major depressive episode in a prospective study. Journal of Affective Disorders, 123(1-3), 123-13

Mac Giollabhui, N., Hamilton, J. L., Nielsen, J., Connolly, S. L., Stange, J. P., Varga, S., \& ... Alloy, L. B. (2018). Negative cognitive style interacts with negative life events to predict first onset of a major depressive episode in adolescence via hopelessness. Journal of Abnormal Psychology, 127(1), 1-11. doi:10.1037/abn0000301

Hankin, B., Abramson, L., \& Siler, M. (2001). A Prospective Test of the Hopelessness Theory of Depression in Adolescence. Cognitive Therapy and Research, 25(5), 607-632.

Himelhoch, S., \& Njie-Carr, V. (2016). "God loves me no matter how I am": a phenomenological analysis of the religious and spiritual experiences of HIV-infected African-American women with depression. Mental Health, Religion \& Culture, 19(2), 178-191.

International Agency for Research on Cancer (IARC). (2013). Latest world cancer statistics. Diambil dari https://www.iarc.fr/en/media-centre/pr/2013/pdfs/pr223_E.pdf 
Kementerian Kesehatan Republik Indonesia. (2013). Riset Kesehatan Dasar 2013 (Riskesdas). Diambil dari http://www.depkes.go.id/resources/download/general/Hasil\%20Riskesdas\%202013.pdf

Khalil, A. A., \& Abed, M. A. (2014). Perceived Social Support is a Partial Mediator of the Relationship Between Depressive Symptoms and Quality of Life in Patients Receiving Hemodialysis. Archives of Psychiatric Nursing, 28(2), 114-118

McCullough, M. E., Emmons, R. A., \& Tsang, J.A. (2002). The grateful disposition: a conceptual and empirical topography. Journal of Personality And Social Psychology, 82(1), 112-127.

Mitchell, A. J., Chan, M., Bhatti, H., Halton, M., Grassi, L., Johansen, C., \& Meader, N. (2011). Prevalence of depression, anxiety, and adjustment disorder in oncological, haematological, and palliative-care settings: a meta-analysis of 94 interview-based studies. The Lancet. Oncology, 12(2), 160-174. doi:10.1016/S1470-2045(11)70002-X

Noronha, K. J. (2015). Impact of Religion and Spirituality on Older Adulthood. Journal of Religion, Spirituality \& Aging, 27(1), 16-33. doi:10.1080/15528030.2014.963907

O’Neill, C., McCaughan, E., Semple, C. J., \& Ryan, A. (2018). Fathers' experiences of living with cancer: a phenomenological study. European Journal of Cancer Care, 27(1), 1

Peeters, F., Berkhof, J., Delespaul, P., Rottenberg, J., \& Nicolson, N. A. (2006). Diurnal mood variation in major depressive disorder. Emotion (Washington, D.C.), 6(3), 383-391

Saldaña, J. (2009). The coding manual for qualitative researchers. SAGE Publications Ltd: London.

Schmid-Büchi, S., Halfens, R. G., Dassen, T., \& van den Borne, B. (2011). Psychosocial problems and needs of posttreatment patients with breast cancer and their relatives. European Journal of Oncology Nursing: The Official Journal of European Oncology Nursing Society, 15(3), 260-266. doi:10.1016/j.ejon.2009.11.001

Seligman, M. E. P., \& Csikszentmihalyi, M. (2000). Positive psychology: An introduction. American Psychologist, 55(1), 5-14. doi:10.1037/0003-066X.55.1.5

Seligman, M. E. P., Steen, T. A., Park, N., \& Peterson, C. (2005). Positive psychology progress: empirical validation of interventions. The American Psychologist, 60(5), 410-421.

Snodgrass, J., \& Sorajjakool, S. (2011). Spirituality in Older Adulthood: Existential Meaning, Productivity, and Life Events. Pastoral Psychology, 60(1), 85-94

van den Beuken-van Everdingen, M. J., de Rijke, J. M., Kessels, A. G., Schouten, H. C., van Kleef, M., \& Patijn, J. (2009). Quality of life and non-pain symptoms in patients with cancer. Journal of Pain And Symptom Management, 38(2), 216-233. doi:10.1016/j.jpainsymman.2008.08.014

Watkins, P. C. (2014). Gratitude and the good life: Toward a psychology of appreciation. New York, NY: Springer Science + Business Media. https://doi.org/10.1007/978-94-007-7253-3

Whitmer, K. M., Pruemer, J. M., Nahleh, Z. A., \& Jazieh, A. R. (2006). Symptom Management Needs of Oncology Outpatients. Journal of Palliative Medicine, 9(3), 628-630.

Wink, P., \& Dillon, M. (2008). Religiousness, spirituality, and psychosocial functioning in late adulthood: findings from a longitudinal study. Psychology and Aging, 18(4), 916-924. 